\title{
Argument for Evidence-Based Development of Sustainable Normative Framework for Nautical Tourism Ports: Case of Croatia
}

\author{
Tihomir Lukovića, Damir Piplicab ${ }^{b}$ Domagoj Hruškac
}

\begin{abstract}
Optimization of nautical tourism development largely depends on national normative frameworks since the use of maritime property is highly regulated in every country. This paper argues that the normative regulation of nautical tourism should take into consideration the historical relation between the key determinants of economic development. The paper analyzes a 15-year period (2005-2019) with respect to six crucial indicators of nautical tourism development: the number of ports, marinas, berths, employees, coast size (aquatorium), and
\end{abstract}

\section{KEY WORDS}

$\sim$ Nautical tourism

$\sim$ Development

$\sim$ Nautical tourism ports

$\sim$ Marinas

$\sim$ Regulations

$\sim$ Classification

$\sim$ Categorization

$\sim$ Concessions

$\sim$ Croatia

a. University College Aspira, Split, Croatia

e-mail: tiholukovic@gmail.com

b. University of Split, Department of Forensic Sciences, Split, Croatia

e-mail: damir.piplica@gmail.com

c. University of Zagreb, Faculty of Economics and Business, Zagreb, Croatia

e-mail:dhruska@net.efzg.hr

doi: 10.7225/toms.v10.n01.015

This work is licensed under (cc) BY

Received on: Feb 3, 2021 / Revised on: Apr 5, 2021 / Accepted on: Apr 11, 2021 / Published: Apr 20, 2021 revenues. Our research found very strong positive relationship between: the number of nautical tourism ports and revenues $(r$ $=0.931)$; number of marinas and revenues $(r=0.985)$; number of employees in nautical tourism ports and generated revenues $(r=0.960)$; number of nautical tourism ports and number of employees (0.987); number of marinas and number of employees $(r=0.965)$. In addition, an intermediate level of relationship was found between: size of the aquatorium used by nautical tourism ports and income $(r=0.454)$, and size of the aquatorium and number of employees $(r=0.652)$. Finally, the paper reports weak relationships between the number of ports and number of berths $(r=0.353)$; number of berths and number of employees; number of berths and size of aquatorium used $(r=0.335)$. The research results related to size of aquatorium are especially important since the current Croatian regulations based on the system of concessions have a discouraging effect on this aspect of the development of nautical tourism ports.

\section{INTRODUCTION}

Nautical tourism ports are one of the sub-areas of nautical tourism, which is one of the backbones of the economic development of many coastal destinations. Considering the heritage, the Croatian State manages the economic subsystem of nautical tourism ports, conditioning these ports as entrepreneurial entities with a whole series of requirements that characterize their business and development (Kasum et al., 2018). The strong influence of the State is met with comments by the European Union and European Commission suggesting a more liberal attitude of the State towards entrepreneurship as well as a relationship contributing to a faster development of entrepreneurship, e.g. nautical tourism port. 
The development of nautical tourism ports is one of the factors in the general development of economy of coastal Croatia and to some extent of the continental part, especially in terms of a wider development potential (Mihanović, Peronja and Vukić, 2019; Kovačić, Favro and Mezak, 2016). Nautical tourism ports in Croatia, specifically in the coastal area, have multiple meanings (Jugović, Kovačić and Hadžić, 2011). Furthermore, it needs to be emhasized that nautical tourism in Croatia plays a significant role in the overall Croatian tourist market, but also that this fact is not so visible in the absolute statistical yearly turnover. In 2019 , Croatian tourism yielded record results in nautical tourism, in which the revenue of nautical tourism ports increased by $7.2 \%$ compared to 2018 (Central Bureau of Statistics, 2020). In absolute terms, the total revenue of nautical tourism ports in 2019 amounted to 918 million HRK. Since in 2019 the contribution of travel and tourism to GDP (as \% of total GDP) for Croatia was $25.1 \%$ and Croatia's GDP was worth 402.34 billion HRK (World Bank, 2020), tourism yielded the total turnover of 101 billion HRK. Therefore, the income from nautical ports in 2019 was around $0.9 \%$ of the total tourism income. However, the gains from nautical tourism are much higher than the income from nautical tourism ports indicate since it generates other forms of tourism spendings as well as extends the tourist season. Finally yet importantly, the first available data indicates that the nautical tourism sector was especially resilient to the COVID-19 pandemics of 2020. In addition, the impact of nautical tourism ports on the development of destinations is especially significant, primarily in smaller and less developed places where a nautical tourism port takes on the role of local leader and has a rapid effect on the development of entrepreneurship, especially the services. In this way, there is an accelerated revival of the destination. Another significant impact of nautical tourism ports is their role for the charter industry, which together with the nautical tourism port is in close business connection.

The development of nautical tourism ports, especially marinas as the most complex and valuable type of nautical tourism ports, is in direct dependence on the State administration and its goals (Trstenjak, Žiković and Mansour, 2020). The basic influence that the State has on the development of nautical tourism ports is legislation, primarily the regulations on nautical tourism ports' classification and categorization. The dynamics of their change in Croatia has stabilized, and the interval between the two changes to the regulations is 10 years. This paper argues that the changes in the legislation should be embedded in the well-established understanding of the relationship between the key factors of nautical tourism development.

In order to shed light on this important topic, the paper analyzes a 15-year-period (2005-2019) of nautical development in Croatia with respect to six crucial indicators of the development: ports, marinas, berths, employees, coast size (aquatorium), and revenues. The research yielded five strong connections between these indicators: two intermediate connections, and three weak connections. The research results offer a framework of interrelations between the key elements of nautical tourism ports development, representing a basis for nautical tourism development. The paper argues that the legislative framework should rely on these interdependencies in devising regulations on the classification and categorization of nautical tourism ports. In the case of Croatia, this is especially important from the aspect of the importance of the size of aquatorium used for nautical ports since that segment of the model is hindered by the current regulations based on the concession system.

\section{ANTECEDENTS AND CONSEQUENCES OF NORMATIVE FRAMEWORK REGULATING NAUTICAL TOURISM DEVELOPMENT IN CROATIA}

\subsection{Evolution of Regulations and Their Current Content}

The link between legislation and nautical tourism port research used to be functional and close. Over time, there has been criticism coming from the research community concerning the Croatian legislation on nautical tourism, primarily nautical tourism ports, so this closeness has gradually faded. The first criticism of the regulations related to nautical tourism ports was voiced thorough the last decade (Luković, Šerić 2009; Luković 2009, Luković, Lapko and Vuković 2018) and has been an important topic ever since. In practice, categorization of nautical tourism ports is determined by administrators from the Ministry of Tourism and Sports, and the Ministry of Sea, Transport and Infrastructure. The State administration is therefore the only subject to design, propose, make and implement decisions concerning nautical tourism port industry, which is then reflected on the sailing charter as an activity related to nautical tourism ports. In this segment of the research, the paper presents the development of three parts of nautical tourism regulations: (1) key regulation documents, (2) national strategies of nautical tourism development, which should be the origin of regulatory framework, and (3) format of national statistics in the area of nautical tourism.

In a recent paper, Vuković and Mišić (2019:613-614) describe the major steps of early regulatory indiscreteness: "Before the current 'Regulation on Classification and Categorization of Ports for Nautical Tourism', the matter of classification and categorization of nautical tourism ports was regulated by three normative acts. 'Regulation on the types and categories of nautical tourism ports and the minimum technical requirements that must be met by organizations for the provision of services for nautical tourism' that classified nautical tourism ports into the following types: a) anchorage, b) mooring, c) tourist port, d) marina, e) nautical-tourist center. Then, the 'Rulebook on Nautical Tourism Ports' was adopted, which did not change the 
classification of nautical tourism ports. Significant changes were made by the 'Regulation on classification and categorization of nautical tourism ports', which included the following in the catalog of nautical tourism ports: a) anchorage, b) mooring, c) dry marina and d) marina."Thus, in the period from 1990 to 2008, the issue of nautical tourism ports was regulated by the three acts that did not differ significantly until the last regulation from 1999.

The significant changes were introduced by the 1999 'Regulation on classification and categorization of nautical tourism ports', which set 4 types of nautical tourism ports: a) anchorage, b) mooring, c) dry marina, and d) marina, which was not accepted by the eponymous regulation entered into force in June 2008. Rough changes followed in terms of abolition of 'moorings' and introduction of 'landfills' as new nautical tourism ports. This regulation was the final turning point in the evolution of nautical tourism port legislation although the classification of nautical tourism ports under this regulation inherited the classification from the previous regulation. The changes that have occurred in the categorization of marinas are especially importan, because the regulation set minimum requirements for all four types of nautical tourism ports: (1) general minimum conditions, (2) infrastructure and waste disposal, (3) room height, (4) nautical tourism port capacity, (5) catering facilities for serving drinks, beverages and food, and other facilities, and (6) staff.

Furthermore, as far as the categorization of nautical tourism ports is concerned, only marinas were categorized according to the anchor system ranging from two to five anchors. The general conditions for categorization were: (1) quality of equipment and decoration, (2) standard of services, (3) variety of complementary services provided to tourists in the marinas, (4) other services and facilities available to tourists in the immediate vicinity of marinas, and (5) quality of maintenance of a marina as a whole.

In this, a strong influence of the State administration in the nautical tourism ports was evident. To strengthen this, the regulation brought a special appendix related to the criteria, which closely elaborated ten issues a marina must meet to achieve the category required: (1) reception services; (2) berths for vessels; (3) common toilet for tourists in the marina; (4) family bathroom; (5) catering facilities for preparation and serving of drinks, beverages, and food; (6) trade and sports services; (7) service, fuel supply of vessels, and other services; (8) environmental protection; (9) premises for employed staff that are not subject to sanitary supervision; (10) quality of devices, equipment, and maintenance of the marina.

The 2008 regulation was particularly significant in this respect as it opened up a number of problems and criticisms, primarily due to the abolition of 'moorings', with the introduction of a new nautical tourism port 'landfill', which further derogated the Croatian legislative system of nautical tourism ports. Earlier, at the highest levels of the profession, discussions were opened about the 'dry marina' as a legalized, but unacceptable port of nautical tourism (Kundih, 2019). According to Article 8, the regulation states: "A landfill for vessels is a part of the mainland fenced and arranged for the provision of services for the disposal of vessels on land and the provision of services for transport, launching and lifting of vessels from the water. Tourists cannot stay in the landfill of vessels and the preparation of the vessel for navigation cannot be performed". In addition, in Article 9, the next type of nautical tourism port, i.e. a dry marina, is defined as: "The dry marina is a part of the mainland fenced and arranged for the provision of services for the storage of vessels on land and the provision of services for transport, launching and lifting of the vessel. Unlike the dumps of vessels, tourists can stay in the dry marina; then, the vessel can be prepared for navigation as well as the provision of beverages and food. "

However, there is an important difference between a dry marina and a landfill. Firstly, the legislator has prevented the provision of food and beverage services, which is not in line with the intention to develop entrepreneurship. Secondly, these types of legalized nautical tourism ports lack real characteristics of the port. In general, the definitions of a dry marina and a landfill are almost indistinguishable, and they cannot be considered by any means to be specialized except that they contain vessels in storage (Vuković, Mišić, 2008). The demands of the European Union and the European Commission to encourage the development of entrepreneurship (indirectly, the port of nautical tourism) have so far remained unanswered at the level of the State administration and policy (Alpeza et al., 2019).

In addition to laws and bylaws related to nautical tourism, other important documents are strategies. The latest strategy related to nautical tourism is the Strategy for the Development of Nautical Tourism of the Republic of Croatia until 2020. The first strategy for the development of nautical tourism was adopted for the period from 2006 to 2016. Due to the non-existence of the implementation sub-system as well as the unfavorable development climate in Croatia, the strategy remained unchanged every year from 2009 to 2019 until the need for a new tourism development strategy emerged. The new document issued by the Ministry of Tourism and Sports - 'Information on initiating the process of strategic assessment and preparation of a strategic study - determining the content and scope of strategic studies on environmental impact assessment for the Strategy for Sustainable Tourism Development until 2030 as well as the National Plan for Sustainable Tourism Development 2021-2027' should be two pivotal reference points for further development of nautical tourism in Croatia.

Another important document is the 'Act on the Provision of Services in Tourism' (Official Gazette 42/20, entered into force in April 2020), which tackles nautical tourism in Articles 84 to 89. Article 84 defines nautical tourism as follows: "Nautical tourism 
is the navigation and stay of tourists (sailors and passengers) in vessels (yacht, boat or ship) for personal needs or economic activity as well as stays in nautical tourism ports". Article 86 briefly defines nautical tourism ports as marinas, as well as anchorage, dry marina and landfill, while mooring is omitted. Eight months later, in December 2020, 'Regulation of the categorization of nautical tourism ports and the classification of other facilities for the provision of berth services and accommodation of vessels' was adopted. Furthermore, Article 5 of the 'Law on the Provision of Services in Tourism' states who can deal with the provision of services in tourism. This part of legislature does not mention State institutions or municipalities as potential subjects in this area. Nevertheless, they often enter the market and thus preform an unfair competition to marinas independently or through their associated special purpose entities providing mooring services to tourist vessels.

The third important part of the State document is related to the national statistics reports. If we consider the document 'Nautical Tourism, Capacities and Operations of Nautical Tourism Ports in 2019' (National Bureau of Statistics, 2020), which was adopted six months after the above mentioned regulation, it can be seen that Croatia has a total of 167 nautical tourism ports, 75 anchorages, 9 moorings, 17 dry marinas, and 5 landfills, with 61 marinas categorized through as many as seven categories. The seven categories shown range from two groups of the old first category and one group of the old second category to four groups categorized by anchors. Therefore, this State document recognizes as nautical tourism ports: a) anchorage, b) mooring, c) dry marina, d) landfill as well as 7 different types of categorized marinas. It is interesting that in the previous year (2018), the same document recognized 142 ports as nautical tourism ports, i.e. a) 62 anchorages, b) 6 moorings, c) 14 dry marinas, d) 58 marinas in total, of which 36 marinas from the first to the third category, 22 marinas categorized by anchors, and e) 2 unclassified ports. Thus, the Central Bureau of Statistics has its own criteria related to nautical tourism ports and, according to the types of nautical tourism ports, classifies them into five types: anchorage, mooring, dry marina, landfill, and marina.

The detailed analysis of key normative documents, national strategies and practices of national statistics indicates that the area of nautical tourism in Croatia is burdened with an inherited ambiguity of terms and inadequate communication between key stakeholders.

\subsection{Consequences of Regulation Ambiguity: Analysis of Blocked Potential Capacities of Nautical Tourism Ports}

As the first 'Strategy for the Development of Nautical Tourism of the Republic of Croatia 2006 to 2016' showed and subsequent strategies confirmed, it is estimated that Croatia's offer in the field of nautical tourism ports should be about 40,000 berths, which in the 'Strategy 2020', Chapter 5.2.1.2. named 'Nautical tourism (yachting/cruising)' revised from the existing cca. 18,000 to additional 15,000 berths: "Construction of 15,000 new berths, of which 5,000 in the sea in marinas, 5,000 in ports open to public traffic, and 5,000 on land". Now Croatia has 18,179 berths, not much more than in previous years. There is no doubt that the strategy regarding the number of berths was not implemented. In the strategic documents prior to 2020, in the same chapters the need was stated for additional capacities related to: nautical tourism ports, marinas for mega yachts, additional home ports for domestic cruising ships, ports open to public traffic, and devastated areas.

Another issue of consequence is that certain parts of the industry are still not regulated. For instance, domestic cruising is not clearly included in the nautical tourism of Croatia, but is singled out in the group of 'small ships'. It consists of about 180 small cruisers for one-day and multi-day cruises as well as groups of cruisers in the central and northern Adriatic. The group of'small shipowners' is organized through two associations that together count about a little over 300 domestic cruisers. For example, an enterprising and well-organized group of cruiser owners in Krilo near Omis is planning to build a special port to accommodate their cruisers. The name and status of this type of port in Krilo as well as possible similar ports that can be expected only for the accommodation of domestic cruisers is unknown to Croatian legislation.

Another potential of development that needs more attention by the regulators are sports ports, i.e. maritime sports associations that, due to the inadequate Sports Act (Official Gazette 77/20), are still not able to engage directly in commercial activities. This means that under public pressure in December 2020, Article 9 of the Law on Associations allowed associations to perform economic activities, but with certain changes to the statute, accounting, and compliance. For this amendment, which followed at the end of 2020, the legal condition is that the economic activity of the association must not make profit. However, the potential of this segment of nautical tourism port development is still questionable and inaccessible.

Furthermore, local ports, public and communal, some of which are still outlawed, are another example of suboptimal development. Most of them do not have a resolved legal status, and those that do not have the possibility of commercial activity are in most cases poorly organized.

Finally, many illegal buoys in bays along the entire Adriatic show an inadequate approach by the relevant Ministry to legalize and charge for anchoring, thus opening up new development opportunities within the law. 


\section{TWO ASPECTS OF NAUTICAL TOURISM PORTS DEVELOPMENT}

\subsection{The Social and Political Aspects of Croatian Nautical Tourism Ports}

Nautical tourism ports, especially marinas but also moorings, are important for the development of underdeveloped destinations along the Croatian Adriatic coast as well as for islands (Vidučić, 2008). Marinas located in an underdeveloped destination assume the role of local economic leaders and rapidly affect the economic development of the destination. This phenomenon is especially important for islands because it enables the employment of island residents, who thus avoid the need to leave the island (Luković, Bilić 2007; Slišković, Ukić and Marušić, 2016).
Previously criticized nautical tourism ports, i.e. the unacceptability of dry marinas and landfills as nautical tourism ports, as well as other facilities that are in the same group with anchorage and mooring, as well as the specificity of ports and cruisers of small shipping companies indicate the need for a new classification of nautical tourism in Croatia. Therefore, it is necessary to develop and establish the system of operational operation of nautical tourism as well as the subsystem of nautical tourism ports and then to cover it by laws that must not be changed in the long run. The paper argues that in order to improve this situation there should be a reexamination of the relation among three key subjects in the development of nautical ports and nautical tourism in general. The current relations among them are presented in Figure 1.

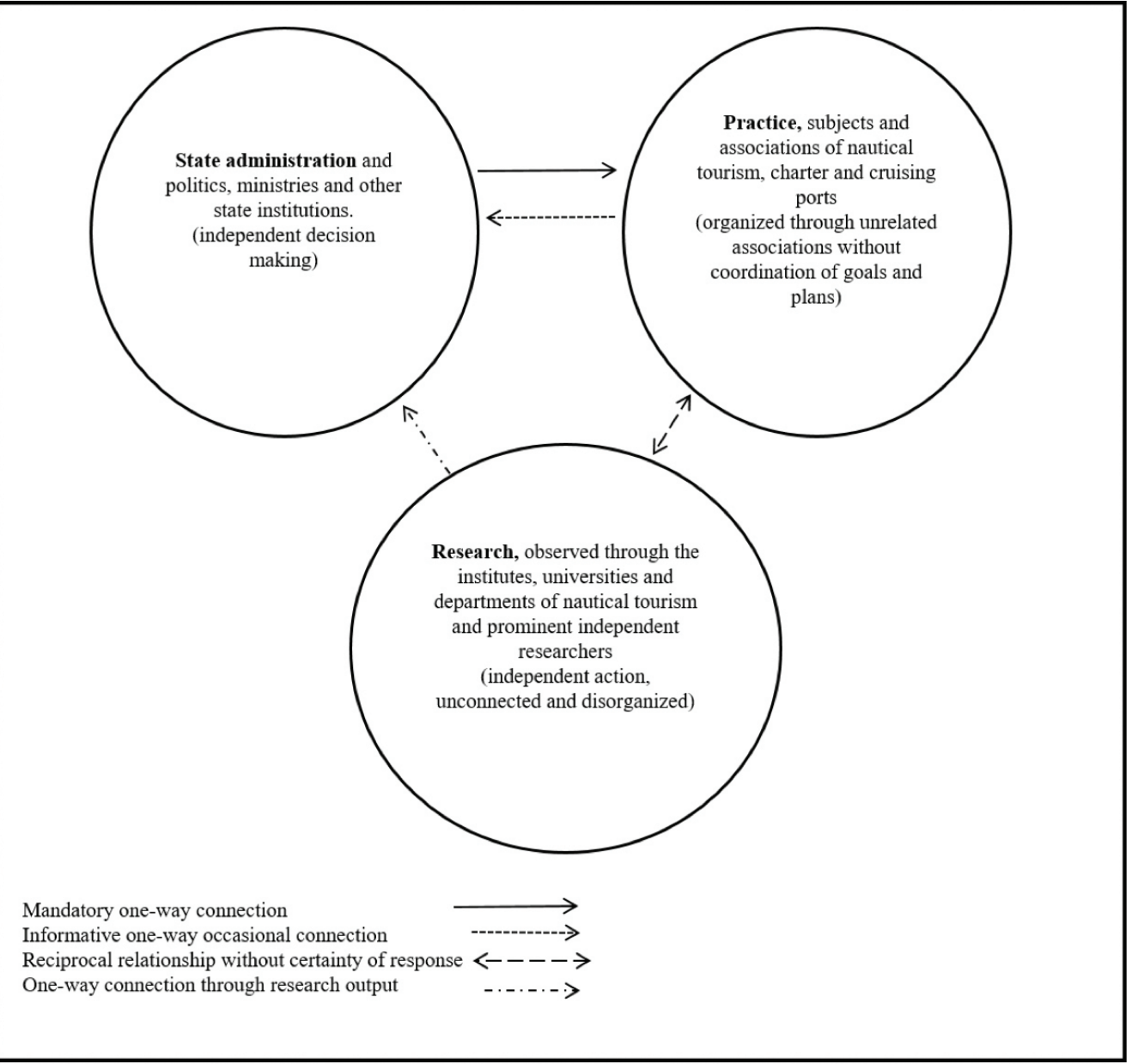

Figure 1.

Key stakeholders in the development of nautical tourism ports and nautical tourism. 


\subsection{Competitive Aspects of Croatian Nautical Tourism Ports}

It is indisputable that nautical tourism ports significantly contribute to local and regional development on the coast and on the islands, and if this phenomenon were understood and politically enabled, the results would be much better. Each of the industries within the nautical tourism sector is organized into an association, sometimes on the national level and sometimes regional. Each industry within the sector needs to cooperate with other industries within the strategic eco-system. A classification of nautical tourism ports is given in Table 1.

Table 1.

Model of nautical tourism classification according to the principle of basic activities (after 2019).

NAUTICAL TOURISM INDUSTRY

\section{SECONDARY ACTIVITIES}

2.

SUPPLEMENTARY ACTIVITIES

Dry dock

\begin{tabular}{|c|c|c|c|c|c|}
\hline \multirow{2}{*}{$\begin{array}{l}\text { Diving tourism } \\
\text { Surfing }\end{array}$} & \multicolumn{2}{|c|}{$\begin{array}{l}\text { Doing business at the port of nautical } \\
\text { tourism and port - related activities }\end{array}$} & \multicolumn{2}{|c|}{ Cruising } & \multirow{2}{*}{$\begin{array}{l}\text { Dry dock } \\
\begin{array}{l}\text { Shipbuilding of } \\
\text { mega yachts }\end{array}\end{array}$} \\
\hline & $\begin{array}{l}\text { Nautical tourism } \\
\text { ports }\end{array}$ & Charter & $\begin{array}{l}\text { Small shippers } \\
\text { (local cruising) }\end{array}$ & $\begin{array}{l}\text { Ports for receiving } \\
\text { large cruisers }\end{array}$ & \\
\hline Rafting & Anchorage & $\begin{array}{l}\text { Motor boats with } \\
\text { and without } \\
\text { skipper }\end{array}$ & Day trips & a) Large city ports & $\begin{array}{l}\text { Production of small } \\
\text { vessels }\end{array}$ \\
\hline Submarine & Mooring & $\begin{array}{l}\text { Sailing boats } \\
\text { with and without } \\
\text { skipper }\end{array}$ & $\begin{array}{l}\text { Multy-day } \\
\text { excursions with } \\
\text { accommodation } \\
\text { service }\end{array}$ & $\begin{array}{l}\text { Cruise Europe } \\
\text { members }\end{array}$ & $\begin{array}{l}\text { Production of } \\
\text { equipment }\end{array}$ \\
\hline Rowing & $\begin{array}{l}\text { Marinas, by } \\
\text { category }\end{array}$ & & & Non members & Skipper service \\
\hline
\end{tabular}

Fishing tourism

b) Other small local Information service ports
Sailing schools

Research institutes and educational centres

\section{Others}

Other services

\section{BASIC FIELD OF RESEARCH}

As it can be seen from Figure 1, the framework proposed differs significantly with regard to the current legislation on the classification of nautical tourism, especially in the segment of nautical tourism ports. Ports are defined as marinas, moorings and anchorages, which with regard to berths and business at sea have all the characteristics of nautical tourism ports. The dry marina and the landfill have been moved to the section 'additional activities' or activities in which they are equated because what divides them is the 'provision of catering services' or non-provision, which in our understanding is not sufficient to act as a classification attribute. It should be noted that the categorization of marinas is not uniform through Europe. In Croatia, the classification changed in June 2008, remained unaltered in the most recent regulations from 2019, and is still not consistent with the industry developments.

As in other segments of development, the cooperation between industries in the sector is somewhat harder to implement due to ambiguous regulations because in order to find most suitable solution for all parties there has to be a mutual agreement on goals and rules. For example, in the 2020 conditions of COVID-19 crisis, there was a turmoil between the Association of Marinas and the Charter Association. Instead of 
too expensive and unprofitable for business in the domain of nautical tourism ports. In 2019, they employed 1,901 workers, and the associated sail charter employed additional 1,830, which together sums up to slightly less than 4,000 employees. Their joint revenues in 2019 were around 500 million Euros, and if we take into consideration that the indirect effects are about four times greater than the stated direct effects, the importance of nautical tourism ports, i.e. marina business (marinas and charter together) is extremely important for the island economy and the Croatian coast.

\section{RESULTS}

After the analysis of antecedents and consequences of development of nautical tourism ports in Croatia, the paper focuses on the key development indicators (through the 15-yearperiod from 2005 until 2019) that will provide us evidence for recommendations for future changes in the normative framework.
For the purpose of evaluation of the dynamics of development of nautical tourism ports, the paper analyzes six key indicators. The number of marinas is certainly a significant issue, but the number of berths is an even more important one because berths are a realistic indicator of the supply capacity. If we take into consideration wider impacts of nautical tourism ports, the number of employees is the major issue because it indicates the real engagement of nautical tourism ports, given that the real resources of the port are berths and human potential. The water area in use (aquatorium) is an indicator, which on the one hand represents the engaged capacities of the maritime domain without which there would be no nautical tourism port, and on the other hand, it represents a significant burden on the port operations due to the model of concessions. Finally, revenues are an indicator of business success that comes as a result of many factors, primarily the resources involved, the aptitude of management as well as a reflection of the demand market. The movement of these crucial indicators is presented in Table 3.

Table 3.

Movement of basic indicators of nautical tourism port development from 2005 to 2019

\begin{tabular}{lllllll} 
& $\begin{array}{l}\text { Ports of nautical } \\
\text { tourism }\end{array}$ & Marinas & Berths & Employees & Aquatorium $\left(\mathrm{m}^{2}\right)$ & $\begin{array}{l}\text { Revenues } \\
(000 \text { HRK })\end{array}$ \\
\hline 2005 & 84 & 43 & 15,058 & 1,160 & $3,901,705$ & 368,116 \\
\hline 2007 & 94 & 47 & 15,834 & 1,209 & $3,309,958$ & 439,178 \\
\hline 2009 & 98 & 49 & 16,848 & 1,319 & $3,293,558$ & 543,376 \\
\hline 2011 & 98 & 50 & 17,059 & 1,328 & $3,293,891$ & 600,225 \\
\hline 2013 & 106 & 53 & 16,940 & 1,387 & $3,278,064$ & 686,660 \\
\hline 2015 & 121 & 57 & 17,351 & 1,586 & $3,614,784$ & 753,412 \\
\hline 2017 & 140 & 57 & 17,067 & 1,665 & $3,711,951$ & 855,166 \\
\hline 2019 & 167 & 61 & 18,179 & 1,901 & $4,349,270$ & 918,495 \\
\hline
\end{tabular}

Depending of the goals of the legislative body, each normative act yields a certain kind of results. If we take into consideration this 15-year-period, we can conclude that the regulation encouraged the rise in the number of ports, while the number of berths and the aquatorium used increased very slightly during the period observed. To gain a better insight into the relations between these development indicators, the paper presents the results of the correlation analysis. The results of correlation analysis together with the explanations concerning the Croatian context of nautical tourism ports are given in Table 4. 
$7 \quad$ BERTHS: REVENUES $(Y=7631.3514+0.0109 X) ; r=0.353$

Discussion: between the number of berths as the most important segment of nautical tourism port offer and revenues, at first glance the relation is of weak medium level. A low degree of berth development of only $1.35 \%$ per year with even a negative annual percentage growth of vessels on a permanent berth of -0.84 indicate that the growth of revenue of nautical tourism ports of as much as $7.29 \%$ per year does not depend on capacity development, but on prices as well as other services.

8 EMPLOYMENT: INCOME $(Y=638.4212+0.0012 X) ; r=0.960$

Discussion: There is a very high positive correlation between the number of employees in nautical tourism ports and the generated revenues. This means that human resources significantly affect the revenues of nautical tourism ports. Satisfaction with services, apart from the content and offer of nautical tourism ports, especially marinas, depends on the communication and attitude of marina staff towards guests of nautical tourism ports.

$9 \quad$ AQUATORIUM $\left(\mathrm{m}^{2}\right)$ : INCOME $(\mathrm{Y}=3.0125+0.9009 \mathrm{X}) ; \mathrm{r}=0.454$

Discussion: An intermediate strength of connection was established between the maritime domain, waters used by the nautical tourism ports, and the revenue. Since under the Croatian normative framework the use of the waters is related to the payment of the concession (fixed and variable), it is understandable that nautical tourism ports are reluctant to increase existing new water areas. This clearly indicates that the concession system significantly inhibits the development of nautical tourism ports in Croatia. Given this fact, the overall development of nautical tourism ports is not only stagnant, as evidence on number of berths in the 15-year-period indicates, but is in decline.

10 BERTHS: AQUATORIUM $(Y=5163.1520+0.0055 X) ; r=0.355$

Discussion: between the number of berths of nautical tourism ports and the water area used, a weak medium intensity connection was established, i.e. the mutual influence is slight. This means that the number of berths is developmentally limited since the normative framework enacts limitations of cost used in nautical tourism ports. With respect to the demand factor, the number of berths have the potential to grow, but since the aquatorium remains unchanged, so does the number of berths.

\section{DISCUSSION AND CONCLUSION}

The research results in line with the movement of six basic indicators of nautical tourism port development identified ten relationships as presented in Croatian context of nautical tourism ports. The paper argues that the results of the relationship among the indicators illustrate the problems identified earlier in the text as well as the causes of the problems. The study showed five correlation coefficients that reflect a strong, almost complete functional relationship. At the same time, the research showed two correlation coefficients as indicators of a medium-strong relationship (aquatorium - employees; and aquatorium - income) as well as three coefficients that show a low relationship strength.

Our research indicates that the indicators displaying a lag in the development of nautical tourism ports in Croatia are primarily connected to the concession system that proved to be unstimulating from the point of long-term development. At the same time, the current as well as the previous strategies for the development of nautical tourism indicate the need to increase the capacity of the offer. This primarily refers to berths in nautical tourism ports. Since berth capacities depend on the waters engaged, it is clear that in the segment of normative framework of the use of maritime property, changes need to be made. Increased capacities are related to revenues as well as the number of employees, which confirms a wider importance and need for these changes.

The paper argues that an indicator showing the lowest dynamics in the observed 15-year-period, i.e. the size of aquatorium, is the indicator that provides the most important research insight. A more dynamic use of the water area must stimulate growth in the number of berths, but according to the research results, their mutual correlation coefficient is 0.355. In addition, a larger number of employees must power a larger number of berths, with the condition of better focus on larger capacities of the water area. Likewise, a larger water area encourages a larger number of berths, and a larger number of 
berths encourages higher revenues. However, since the expensive concession stifles the desire of nautical tourism ports for a larger water area, this expansion of the water area is avoided.

The economic policy of Croatia on the example of nautical tourism ports is not consistent and congruent since it does not encourage the results presented. If the basic goal of the State concerning the nautical tourism are short-term fiscal gains, then the existing regulations can be justified. However, if the goal is to support investments and the development of nautical tourism ports, which is a significant factor of the development of islands and less developed areas of the Adriatic Coast, then it is necessary to rethink the existing system and develop the legislation accordingly. This means that it is necessary to define long-term development goals, according to their plans, and then set up subsystems of implementation as well as controlling, i.e. the subsystem of supervision, which monitors the realization of the goals planned. In this way, a dynamic system can be formed which will have the capacity to effectively manage a further development of nautical ports in Croatia to maintain and increase competitive advantage of nautical tourism in the eastern Adriatic.

\section{REFERENCES:}

Alpeza, M. et al., 2019. Small and Medium Enterprises Report - Croatia 2019 including the results of GEM - Global Entrepreneurship Monitor research for Croatia for 2018, CEPOR - SMEs and Entrepreneurship Policy Center, Zagreb.

Croatian Bureau of Statistics, 2020. Nautical tourism, Capacities and operations of nautical tourism ports in 2019, Repubic of Croatia.

Decision on initiating the procedures for drafting the Strategy for the Development of Sustainable Tourism until 2030 and the National Plan for the Development of Sustainable Tourism 2021 - 2027, Repubic of Croatia, 2020.

Gračan, D., Gregorić, M. and Martinić, T., 2016. Nautical tourism in Croatia: current situation and outlook, 23rd Biennial International Congress, Tourism and Hospitality Industry 2016, Trends and Challenges, Opatija, Hrvatska, 28-29th April 2016.

Information on initiating the strategic assessment process and preparation of a strategic study - determining the content and scope of strategic studies on environmental impact assessment for the Sustainable Tourism Development Strategy until 2030 and the National Sustainable Tourism Development Plan 20212027, Ministry of Tourism and Sports, Repubic of Croatia, 2020.

Jugović, A., Kovačić, M., Hadžić, A., 2011. Sustainable Development Model for Nautical Tourism Ports. Tourism and Hospitality Management, 17(2), pp. 175-186.

Kasum, J., Žanić Mikuličić, J. and Kolić, V., 2018. Safety Issues, Security and Risk Management in Nautical Tourism, Transactions on Maritime Science 7(2), pp. 184188. Available at:

https://doi.org/10.7225/toms.v07.n02.008.

Favro, S., Kovacic, M. \& Mezak, V., 2016. CONSTRUCTION OF NAUTICAL TOURISM PORTS AS AN INCENTIVE TO LOCAL DEVELOPMENT. Environmental Engineering and Management Journal, 15(2), pp.395-403. Available at: http://dx.doi.org/10.30638/eemj.2016.041.

Kundih, B., 2020. Neka otvorena pitanja i prijedlozi vezani uz turističke i sportske luke i privezišta. Available at: https://www.pomorskodobro.com/aktualno/589-nekaotvorena-pitanja-i-prijedlozi-vezaniuz-turisticke-i -sportske-luke-i-privezista.html.
Luković, T., 2009. Clashing or compatible strategies of development of nautical tourism in Europe, Pomorstvo, 23(2), pp. 341-356.

Luković, T., Bilić, M., 2007a. Ports of nautical tourism in Croatia and the local development strategies - first part, Naše more, 173, pp. 114-122.

Luković, T., Bilić, M., 2007b. Ports of nautical tourism in Croatia and the local development strategies, second part, Naše more, 173, pp. 204-214.

Luković, T., Šerić, N., 2009. Strategic development and changes in legislation regulating nautical tourismin Croatia, Pomorstvo, 23(2), pp. 357-374.

Mihanović, V., Peronja, I. \& Vukić, L., 2019. Port Area of the Split Port Authority in the Function of Economic Development: Concessionaires Attitudes. Transactions on Maritime Science, 8(2), pp.213-218. Available at: http://dx.doi.org/10.7225/toms.v08.n02.006.

Opinion on the need to conduct a strategic environmental assessment for the Strategy for the Development of Sustainable Tourism until 2030, Ministry of Economy and Sustainable Development, (2020).

Opinion on the need to conduct a strategic environmental assessment for the National Plan for the Development of Sustainable Tourism from 2021 to 2027, Ministry of Economy and Sustainable Development, Repubic of Croatia, (2020).

Regulation on classification and categorization of nautical tourism ports, 2004. Repubic of Croatia, Narodne novine, 142/99, 47/00, 121/00, 45/01, 108/01, 106/04.

Regulation on classification and categorization of nautical tourism ports, 2008. Repubic of Croatia, Narodne novine, br. 72/08

Regulation on nautical tourism ports, 1999. Repubic of Croatia, Narodne novine, 109/96, 42/98, 110/99.

Regulation on the categorization of nautical tourism ports and the classification of other facilities for the provision of berth services and accommodation of vessels, 2019. Repubic of Croatia, Narodne novine, 120(19).

Regulation on the types and categories of nautical tourism ports and on the minimum technical requirements that must be met by organizations for the provision of services for the needs of nautical tourism, 1990. Repubic of Croatia, Narodne novine, br. 24/90

Slišković, M., Ukić, H. \& Marušić, E., 2016. Labor Market Need Analysis as Basis for the Foundedness of Occupational Standards in the Field of Maritime Management. Transactions on Maritime Science, 5(1), pp.29-39. Available at: http://dx.doi.org/10.7225/toms.v05.n01.004.

Sports Act, Repubic of Croatia, 2020. Narodne novine, 77/20.

Trstenjak, A., Žiković, S. \& Mansour, H., 2020. Making Nautical Tourism Greener in the Mediterranean. Sustainability, 12(16), p.6693. Available at: http://dx.doi.org/10.3390/su12166693.

Vidučić, V., 2008. Sustainable Development of Maritime Tourism in Croatia 20072015. Transition Studies Review, 15(2), pp.321-333. Available at: http://dx.doi.org/10.1007/s11300-008-0010-9.

Vuković, A., 2019. Novi Pravilnik o kategorizaciji luka nautičkog turizma i razvrstavanju drugih objekata za pružanje usluga veza i smještaja plovnih objekata. Available at: http://www.pomorskodobro.com/u-fokusu-struke/668-fokus-vukovicsvibanj-2020.html.

Vuković, A., Mišić, Ž., 2019. Zašto treba mijenjati pravilnik o razvrstavanju i kategorizaciji luka nautičkog turizma, Zbornik radova Pravnog fakulteta u Splitu, 56(3), pp. 609-625.

World Bank, Economic Indicators, 2021. Available at https://data.worldbank.org/. 